\title{
The formation of agrophytocenoses of sunflower hybrids when using fertilizers in the Middle Volga forest-steppe
}

\author{
Vasily G. Vasin, Denis V. Potapov, Lyudmila V. Kiseleva*, Ramis N. Saniev, and Mikhail A. Zhizhin \\ Samara State Agrarian University, Kinel 446442, Samara region, Russia
}

\begin{abstract}
The methods of increasing productivity of sunflower hybrids using fertilizers and a micronutrient mixture Agromineral in the forest-steppe of the Middle Volga were described. The results of 2017-2018 studies are presented. The leaf area, the photosynthetic potential, the crop structure and the yield at different doses of fertilizers were assessed. The maximum value of the photosynthetic potential is formed by crops of the mid-season hybrid 8 H477KLDM (4.386 million $\mathrm{m}^{2} /$ ha per day). The use of fertilizers and micronutrient mixtures increases the photosynthetic potential and productivity by $9.09 \ldots 9.36 \mathrm{c} / \mathrm{ha}$ with an absolute value of $29.46 \ldots 31.83 \mathrm{c} / \mathrm{ha}$.
\end{abstract}

\section{Introduction}

In Russia, the main oilseed crop is sunflower which is determined by climatic conditions, peculiarities of the raw material and production base, and consumption traditions. The area of sunflower crops is 7.3 million hectares. The demand for this crop has always been and remains high. One of the main factors increasing the economic potential of sunflower is the widespread use of highly productive varieties and hybrids and improvement of cultivation technologies $[1,2]$.

The main advantage of sunflower is oil. The fat content (per dry matter) ranges from 40 to $50 \%$; in new hybrids, it reaches $58 \%$. The oil is of high quality, usually sold in the world market at a higher price compared to soybean, rapeseed, cotton and peanut. Confectionery and bakery products are enriched with sunflower seeds ; they are also used in the production of animal feed as a protein component $[3,4]$.

Sunflower is a drought-tolerant crop, but the yield and quality of its seeds depend on the moisture supply of plants during the growing season. With a powerful root system, it is able to consume moisture from the deep soil layers. However, it does not have special devices for its economical use, as a result of which a rather large amount of moisture is spent on the crop formation.

In comparison with other crops, sunflower requires a special nutritional regime of the soil. One ton of sunflower seeds requires $50-60 \mathrm{~kg}$ of nitrogen, $20-25 \mathrm{~kg}$ of phosphorus and 150-160 kg of potassium [5, 6].

Sunflower cultivation technologies depend on the availability of agricultural machinery and tools. Along with a traditional sunflower growing technology, the Clearfield technology has found application in farms. It is a unique combination of EURO-LIGHTNING ${ }^{\circledR}$ herbicide containing two active imidazolinone substances and high-yielding hybrids resistant to this herbicide $[1,6]$.

The rational use of fertilizers and foliar fertilizers is the basis of effective crop production. Fertilizers affect the consumption of nutrients by plants and their removal with the crop. Sunflower responds to nitrogenphosphorus fertilizers, much less only to nitrogen and phosphorus fertilizers, and does not respond to potash [7].

It is well known that trace elements are a necessary component in the cultivation of high-quality crops. Plant growth regulators affect the productive use of mobile forms of minerals and increase the resistance of plants to stress, diseases, pests. They are a powerful tool for controlling plant ontogenesis, and are widely used for cultivating agricultural plants $[4,5]$.

\section{Materials and methods}

\subsection{Research objects}

The objects were: Sunflower Hybrides - LG 5543, LG 5555, MAC 87, MAC 80, 8H477KLDM, 8H358KLDM, 8H270KLDM, 8H288KLDM; microfertilizer mixture Agromineral and complex fertilizer Nitrabor.

Agromineral (oleate) contains: N - 15.6\%; MgO $2.13 \%$; SO3 - 1.03\%; B - 0.49\%; CU - 0.10\%; Fe $0.49 \%$; Mn $-0.49 \%$; $\mathrm{Zn}-0.49 \%$; Mo $-0.0050 \%$. It is used as a complex mineral fertilizer with trace elements for fertilizing all types of soils. Nitrabor is a unique complex fertilizer, which is a calcium nitrate enriched with boron; it contains nitrogen, water-soluble calcium and boron. The composition of YaraLiva NITRABOR fertilizer: Nitrogen, N - 15.4\%, Nitrogen, nitrite. N-NO3 - $14.1 \%$, Nitrogen, amm. N-NH4 - 1.3\% Calcium, $\mathrm{CaO}$ $25.6 \%, \mathrm{Ca}-18.3 \%$, Boron B - 0.3\%.

\footnotetext{
*Corresponding author: kiseleva_lv@ssaa.ru
} 
The following sunflower hybrides were studied: early ripening - 8H288KLDM, 8H270KLDM, MAC 80 ИР; medium early - 8H358KLDM, LG 5543 KL, LG 5555 KL, MAC 87 IR; mid-season - 8H477KLDM.

The purpose of the research is to develop methods for increasing productivity of sunflower hybrids cultivated using the Clearfield system when applying fertilizers and using modern microfertilizer mixtures in the foreststeppe zone of the Middle Volga.

The research objectives are to assess parameters of plant safety, photosynthetic activity in crops, productivity of sunflower hybrids, depending on the use of fertilizers and Agromineral.

\subsection{Research methods}

The field experiment was conducted in 2017-2018 in the field of Samara State Agrarian University. The soil was chernozem, residual carbonate, medium humus, with a content of easily hydrolyzable nitrogen of 105-127 $\mathrm{mg} / \mathrm{kg}$, mobile phosphorus of $130-152 \mathrm{mg} / \mathrm{kg}$ and exchange potassium of $311-324 \mathrm{mg} / \mathrm{kg}$, PH 5.8 . Humidification was natural.

The agricultural technology was traditional for the zone. Sowing was carried out with a row seeder SUPN-8 in a dotted way with a seeding rate of 65 thousand germinating seeds per 1 ha. Harvesting was carried out in the phase of full ripeness.

In a three-factor experiment, against the background of mineral nutrition (factor A) and crop treatment (factor B), sunflower Hybrides (factor C) were studied. Mineral nutrition options: control (without fertilizers), application of N27P26K26. Fertilizers were applied for the pre-sowing cultivation (Diammofos (10:26:26) and Nitrabor). Options for processing crops during the growing season: without treatment, appication of Agromineral $3.01 /$ ha

Crop was accounted using the method of $10 \mathrm{~m} 2$ harvesting plots in four repetitions with a complete analysis of the crop structure. The number of plants, the mass of baskets, the mass of seeds were identfied, the seed humidity was determined (7\%).

In May 2017, the average air temperature was 14.2 ${ }^{\circ} \mathrm{C}$, which is slightly higher than the long-term average. The total precipitation was $70.4 \mathrm{~mm}$, which significantly exceeds the long-term average data. There were $1.9 \mathrm{~mm}$ of precipitation in the first decade, $17.2 \mathrm{~mm} \mathrm{-} \mathrm{in} \mathrm{the}$ second decade, and $51.3 \mathrm{~mm} \mathrm{-} \mathrm{in} \mathrm{the} \mathrm{third} \mathrm{decade.}$ During the sowing period, there were favorable conditions which is confirmed by quick and friendly seedlings.

The temperature of June was $16.5^{\circ} \mathrm{C}$, which is $2.2^{\circ}$ $\mathrm{C}$ lower than the average annual values. The total precipitation was $129.8 \mathrm{~mm}$, which is 3.3 times higher than the annual average. At this time, the aboveground mass increased, and a powerful root system developed.

The average July temperature was $20.9^{\circ} \mathrm{C}$, with an average annual value of $20.7^{\circ} \mathrm{C}$. Precipitation was 22.4 $\mathrm{mm}$. The maximum amount of precipitation was observed in the first decade $(17.8 \mathrm{~mm})$. In the second decade, the weather was hot and dry which influenced the development of sunflower plants.

In August, the air temperature was slightly higher than the long-term average and amounted to $21.4^{\circ} \mathrm{C}$. At the same time, there was practically no precipitation $1.3 \mathrm{~mm}$, which is almost 3.5 times less than the average annual values. The lack of moisture decreased the yield.

In 2018, sunflower hybrids were sowed at the end of the second decade of May, when the air temperature was $18.9^{\circ} \mathrm{C}$, which is $4.8^{\circ} \mathrm{C}$ higher than the average annual values. There was little rainfall: $13.5 \mathrm{~mm}$ in the third decade.

In the first and second decades of June, the average daily temperature was 13.9 and $17.6{ }^{\circ} \mathrm{C}$. The development of plants was slowed down. In the first two decades, the precipitaion was $7.5 \mathrm{~mm}$ which is much lower than the average one. In the third decade, with an increase in temperature, the amount of precipitation was $11.2 \mathrm{~mm}$ which made it possible to slightly compensate for the lack of moisture.

July was very warm; the average temperature was $23.8{ }^{\circ} \mathrm{C}$, which is $3.1{ }^{\circ} \mathrm{C}$ warmer than the average over the years of observation. During the first decade, the amount of precipitation was $10.6 \mathrm{~mm}$, while the second and third decades were waterlogged -31.3 and $30.8 \mathrm{~mm}$, respectively.

In August, the average daily temperature was $1.3^{\circ} \mathrm{C}$ higher than the average annual values, and moisture with precipitation arrived 3.6 times less.

In general, weather conditions of 2017-2018 were favorable for the cultivation of sunflower, because it was able to use its potential thanks to the use of moisture from the deep soil layers. However, the cold weather of June 2018 affected the duration of the growing season.

\section{Results}

The optimal sowing structure is one of the main productivity factors. The yield per unit area is determined by the number of plants and the mass of one plant. Safety of crops is the most important indicator that directly affects the size of the future crop

In 2017 , safety of plants was in the range of $70.1 \ldots$ $85.8 \%$; due to fertilizers, it was much higher. The maximum safety was observed in 8 H270KLDM (85.8\%) due to the use of fertilizers in conjunction with Agromineral (3.0 1/ ha).

For the two years of research, safety of plants was $71.1 \ldots 78.9 \%$ for all options; the best safety results were observed in MAS 80 and 8H477KLDM (74.7\%); when treated with Agromineral, plant safety increased foro all options. Hybrides 8H477KLDM, 8H358KLDM and $8 \mathrm{H} 288 \mathrm{KLDM}$ responded better to the use of microfertilizer mixtures. In case of mineral nutrition, safety increased and amounted to $81.5 \ldots 88.4 \%$. Without treatment, the best safety results $(87.9 \%)$ were observed in 8 H358KLDM hybrid; 8H270KLDM showed the best safety reslts when treated with microfertilizer mixtures $(88.4 \%)$ (Table 1$)$.

The study of the influence of individual technological methods on the growth and development of crops is 
accompanied by observations of the characteristics of photosynthetic activities in crops.

Table 1. The number and safety of sunflower hybrids for harvesting, depending on fertilizer application and the use of Agromineral, average for 2017-2018.

\begin{tabular}{|c|c|c|c|c|}
\hline 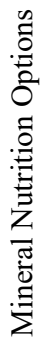 & 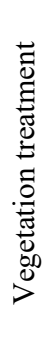 & Hybrids & $\begin{array}{l}\text { The number of } \\
\text { plants, } \\
\text { thousand pes / } \\
\text { ha }\end{array}$ & $\begin{array}{c}\text { Plant safety. } \\
\%\end{array}$ \\
\hline \multirow{16}{*}{ 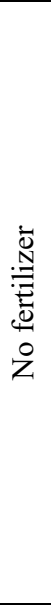 } & \multirow{8}{*}{ 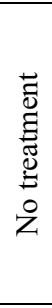 } & LG 5543 & 45.4 & 71.4 \\
\hline & & LG 5555 & 44.9 & 71.1 \\
\hline & & MAC 87 & 46.9 & 74.0 \\
\hline & & MAC 80 & 47.5 & 74.7 \\
\hline & & 8H477KLDM & 46.4 & 74.7 \\
\hline & & 8H358KLDM & 45.4 & 71.2 \\
\hline & & 8H270KLDM & 45.4 & 71.5 \\
\hline & & 8H288KLDM & 49.5 & 77.2 \\
\hline & \multirow{8}{*}{$\begin{array}{l}\stackrel{\pi}{ \pm} \\
\overline{0} \\
\dot{m}\end{array}$} & LG 5543 & 46.9 & 73.3 \\
\hline & & LG 5555 & 48.0 & 75.2 \\
\hline & & MAC 87 & 48.5 & 75.6 \\
\hline & & MAC 80 & 47.5 & 74.7 \\
\hline & & 8H477KLDM & 49.5 & 78.9 \\
\hline & & 8H358KLDM & 50.0 & 78.5 \\
\hline & & $8 \mathrm{H} 270 \mathrm{KLDM}$ & 49.5 & 77.5 \\
\hline & & $8 \mathrm{H} 288 \mathrm{KLDM}$ & 50.0 & 78.7 \\
\hline \multirow{16}{*}{ 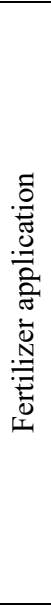 } & \multirow{8}{*}{ 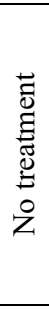 } & LG 5543 & 52.8 & 83.3 \\
\hline & & LG 5555 & 52.3 & 81.5 \\
\hline & & MAC 87 & 51.8 & 82.4 \\
\hline & & MAC 80 & 51.8 & 82.5 \\
\hline & & 8H477KLDM & 52.8 & 84.3 \\
\hline & & 8H358KLDM & 54.9 & 87.9 \\
\hline & & 8H270KLDM & 55.4 & 87.2 \\
\hline & & $8 \mathrm{H} 288 \mathrm{KLDM}$ & 52.3 & 83.3 \\
\hline & \multirow{8}{*}{$\begin{array}{l}\stackrel{\Xi}{\Xi} \\
\vdots \\
\dot{n}\end{array}$} & LG 5543 & 54.9 & 86.1 \\
\hline & & LG 5555 & 54.9 & 86.9 \\
\hline & & MAC 87 & 54.4 & 85.4 \\
\hline & & MAC 80 & 53.3 & 85.0 \\
\hline & & 8H477KLDM & 53.8 & 85.7 \\
\hline & & 8H358KLDM & 54.9 & 86.9 \\
\hline & & 8H270KLDM & 56.4 & 88.4 \\
\hline & & 8H288KLDM & 52.3 & 82.0 \\
\hline
\end{tabular}

This issue is extremely important, since changes in the conditions of plant growth are inevitable, and affect the production process. The main indicators are the leaf area, the photosynthetic potential and the net productivity of photosynthesis.

The favorable environment is required for the greatest efficiency of photosynthesis: optimal air temperature, light intensity, soil fertility, soil moisture. Therefore, it is necessary to regulate these factors through agronomic techniques, such as soil cultivation, planting rates, crop care, weed destruction, as well as the application of mineral fertilizers and the use of plant growth and development stimulants [6].

It is well known that leaves are the main link in photochemical reactions, during which substances are formed. Therefore, an increase in the leaf area and their maximum preservation during the growing season, as well as an increase in the content of chlorophyll is an indispensable condition for obtaining high yields [1].

On average, over two years of research, the area of sunflower leaves was $17.6 \ldots 36.9$ thousand $\mathrm{m}^{2} /$ ha, with a maximum rate for LG 5555 when applying fertilizers and treating crops. Among early ripening hybrids, the best indicator was in MAS $80-36.8$ thousand $\mathrm{m}^{2} /$ ha. When treating crops with Agromineral, the leaf area increases.

MAS 80 showed the best responsiveness to this agricultural method, the leaf area increased by 13.8 thousand $\mathrm{m}^{2} /$ ha. When treating with fertilizers, the leaf area increased by 16.6 thousand $\mathrm{m}^{2} /$ ha .

By the budding phase, an increase in the leaf surface is more intensive. At this time, the maximum leaf area was observed in 8 H477KLDM (90.8 thousand $\mathrm{m}^{2} / \mathrm{ha}$ ), 8 H358KLDM (87.2 thousand $\mathrm{m} 2 / \mathrm{ha})$, and early ripening $8 \mathrm{H} 288 \mathrm{KLDM}$ ( 79.3 thousand $\left.\mathrm{m}^{2} / \mathrm{ha}\right)$. At the same time, due to the use of mineral nutrition crops treatment, all hybrides had the maximum leaf surface area.

The reaction to Agromineral was different: the largest increase without fertilizers was observed in early ripening $8 \mathrm{H} 288 \mathrm{KLDM}$ (13.2 thousand $\mathrm{m}^{2} / \mathrm{ha}$ ) compared with mid-early $8 \mathrm{~N} 358 \mathrm{KLDM}$ (27.3 thousand $\left.\mathrm{m}^{2} / \mathrm{ha}\right)$.

In the second half of the growing season, the assimilation surface of sunflower leaves decreased due to the death of lower leaves. By the flowering phase, the area of sunflower leaves was $28.5 \ldots 55.1$ thousand $\mathrm{m}^{2} /$ ha.

In the variants without fertilizers and stimulation, the maximum leaf area was: 37.5 thousand $\mathrm{m}^{2} / \mathrm{ha}$ in 8H477KLDM, 35.1 thousand $\mathrm{m}^{2} / \mathrm{g}$ in LG 5555, 32.2 thousand $\mathrm{m}^{2} / \mathrm{ha}$ - in $8 \mathrm{H} 288 \mathrm{KLDM}$; when applying Agromineral for mid-ripening $8 \mathrm{H} 477 \mathrm{KLDM}$, it was 48.0 thousand $\mathrm{m}^{2} /$ ha, for mid-ripening $8 \mathrm{H} 358 \mathrm{KLDM}-43.6$ thousand $\mathrm{m}^{2} / \mathrm{g}$, for early ripening MAC 80 - 42.1 thousand $\mathrm{m}^{2} /$ ha. MAS 80 reacted better to the use of micronutrient mixtures with an increase in the leaf area by 13.6 thousand $\mathrm{m}^{2} /$ ha.

By the beginning of the browning phase of the basket, the leaf area continued to decline. The largest area was observed in 8 H477KLDM - 31.2 thousand $\mathrm{m}^{2} /$ ha, without fertilizing and treatment - in mid-ripening 8H358KLDM (34.4 thousand $\left.\mathrm{m}^{2} / \mathrm{ha}\right)$. When applying fertilizers and treating with Agromineral, the leaf area in 8H270KLDM was 46.3 thousand $\mathrm{m}^{2} / \mathrm{ha}$ ).

The photosynthetic potential is an integral indicator of the photosynthetic activity of plants and an important attribute associated with the harvest, which is the sum of daily indicators of the leaf area for the entire growing season characterizing the possibility of using solar energy by crops. 1000 units of the photosynthetic potential are formed by $2.5-3.0 \mathrm{~kg}$ of grain.

On average, over two years of research, the highest photosynthetic potential was observed in 8 H477KLDM both without and with fertilizers and a microfertilizing mixture - 4.005 and 4.386 million $\mathrm{m}^{2} /$ ha days, respectively (Table 2). 
Table 2. The photosynthetic potential and net productivity of photosynthesis depending on fertilizers and Agromineral, average for 2017-2018.

\begin{tabular}{|c|c|c|c|c|}
\hline 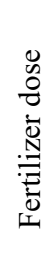 & 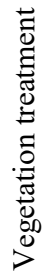 & Hybrids & 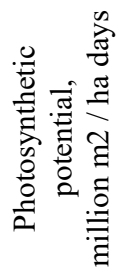 & 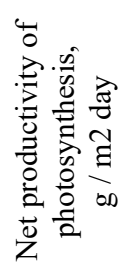 \\
\hline \multirow{16}{*}{ 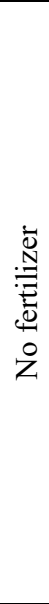 } & \multirow{8}{*}{ 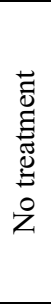 } & LG 5543 & 3,043 & 4,455 \\
\hline & & LG 5555 & 3,022 & 5,811 \\
\hline & & MAC 87 & 3,018 & 6,079 \\
\hline & & MAC 80 & 3,004 & 5,023 \\
\hline & & 8H477KLDM & 3,398 & 4,468 \\
\hline & & 8H358KLDM & 3,008 & 5,331 \\
\hline & & 8H270KLDM & 2,934 & 3,590 \\
\hline & & 8H288KLDM & 2,922 & 5,313 \\
\hline & \multirow{8}{*}{ 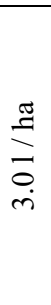 } & LG 5543 & 3,735 & 3,380 \\
\hline & & LG 5555 & 3,640 & 4,620 \\
\hline & & MAC 87 & 3,561 & 4,214 \\
\hline & & MAC 80 & 3,960 & 3,680 \\
\hline & & 8H477KLDM & 4,005 & 3,510 \\
\hline & & 8H358KLDM & 3,611 & 4,581 \\
\hline & & 8H270KLDM & 3,359 & 3,444 \\
\hline & & 8H288KLDM & 3,674 & 4,068 \\
\hline \multirow{16}{*}{ 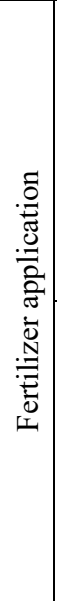 } & \multirow{8}{*}{ 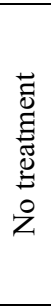 } & LG 5543 & 3,577 & 3,299 \\
\hline & & LG 5555 & 3,721 & 3,310 \\
\hline & & MAC 87 & 3,252 & 4,061 \\
\hline & & MAC 80 & 3,333 & 4,268 \\
\hline & & 8H477KLDM & 3,617 & 4,191 \\
\hline & & 8H358KLDM & 3,248 & 4,473 \\
\hline & & 8H270KLDM & 3,463 & 3,705 \\
\hline & & 8H288KLDM & 3,204 & 4,821 \\
\hline & \multirow{8}{*}{$\begin{array}{l}\stackrel{\Xi}{\Xi} \\
\stackrel{0}{0} \\
\dot{n}\end{array}$} & LG 5543 & 3,647 & 3,522 \\
\hline & & LG 5555 & 4,073 & 3,372 \\
\hline & & MAC 87 & 3,623 & 3,196 \\
\hline & & MAC 80 & 3,981 & 3,338 \\
\hline & & 8H477KLDM & 4,386 & 3,904 \\
\hline & & 8H358KLDM & 4,206 & 3,455 \\
\hline & & 8H270KLDM & 3,425 & 3,761 \\
\hline & & 8H288KLDM & 3,965 & 4,325 \\
\hline
\end{tabular}

In the mid-early block of hybrids, the maximum value of the photosynthetic potential was observed in $8 \mathrm{H} 358 \mathrm{KLDM}$ due to the application of mineral fertilizers and stimulation of crops - 4.206 million $\mathrm{m}^{2} / \mathrm{ha}$ days. In early ripening hybrids, the maximum value in 8H288KLDM reached 3.965 million $\mathrm{m}^{2} /$ ha days under the combined use of fertilizers and stimulants.

It is known that the yield depends on the leaf size and productive work of the leaves which is estimated by the "net photosynthesis productivity" (NPP).

On average, the PPF was $3.196 \ldots 6.079 \mathrm{~g} / \mathrm{m}^{2}$ per day. The maximum values of this indicator were observed in MAC $87-6.079 \mathrm{~g} / \mathrm{m}^{2}$ per day and early riping $8 \mathrm{~N} 288 \mathrm{KLDM}-5.313 \mathrm{~g} / \mathrm{m}^{2}$ day.

I In 2017, hybrid yields ranged from 19.03 to 31.57 $\mathrm{kg} / \mathrm{ha}$, with a maximum value of crops of 8H358KLDM (for the variant with fertilizers and Agromineral at a dose of 3 1/ha) (Table 3 ).
Table 3. The productivity of sunflower hybrids depending on fertilizers and Agromineral for 2017-2018. c/ha (7\% humidity)

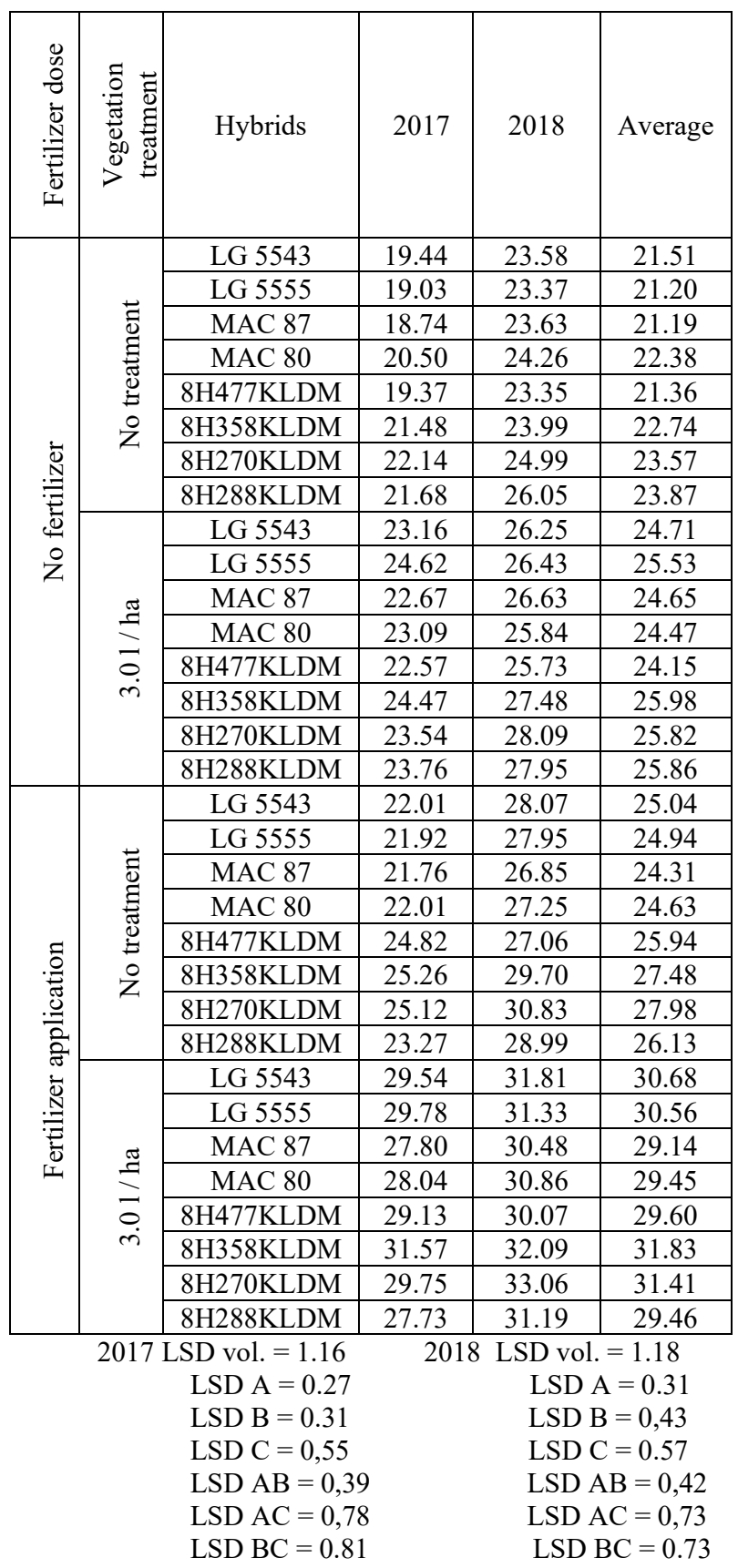

In 2018, the yield was much higher compared to the previous year and reached $33.06 \mathrm{~kg} / \mathrm{ha}$ due to the mineral nutrition and stimulation.

On average, over two years of research, the yield was quite high. Adue to the use of fertilizers, the yield was $21.19 \ldots 23.87 \mathrm{~kg} / \mathrm{ha}$; when using Agromineral, the yield increases, the largest increase was observed in LG 5555 hybrid $-4.33 \mathrm{~kg} / \mathrm{ha}$.

Comparing the levels of mineral nutrition, it can be seen that the highest yield increase was observed for 8H270KLDM - 4.41..5.45 kg/ha, 8H477KLDM - 4.58 ... $5.85 \mathrm{~kg} / \mathrm{ha}$, and $8 \mathrm{H} 358 \mathrm{KLDM}-4.74 \ldots 5.59 \mathrm{~kg} / \mathrm{ha}$.

Treatment with Agromineral increased the yield in both options - without fertilizing (2.0.3.5 c/ ha) and during fertilizing - by 3.3 ... $5.6 \mathrm{c} /$ ha (Fig. 1, 2). 


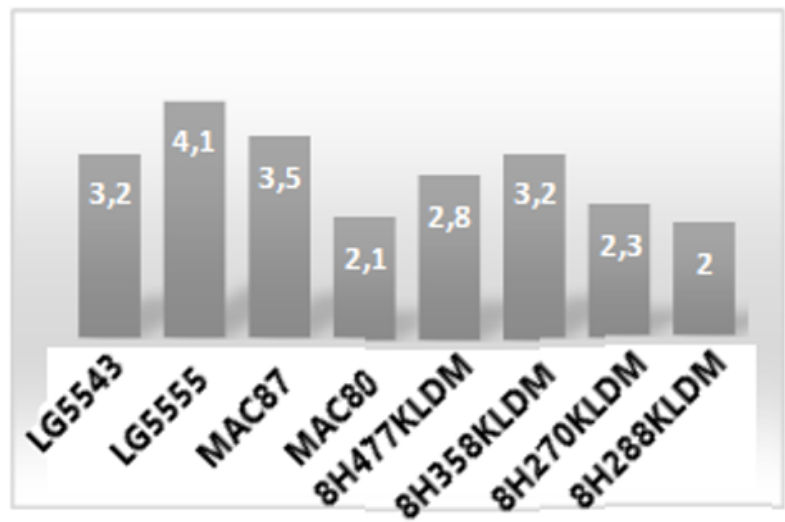

Fig. 1. An increase in the yield of sunflower seeds due to the use of Agromineral without fertilizing

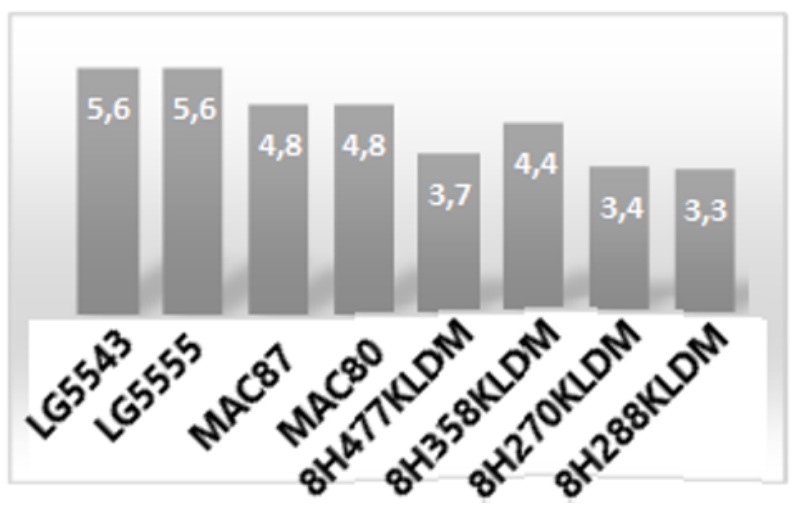

Fig. 2. An increase in the yield of sunflower seeds when using Agromineral and fertilizers

The combined use of microfertilizer mixtures and fertilizers made it possible to obtain a high yield; for 3 hybrids, an increase exceeded $9 \mathrm{c} /$ ha (Fig. 3).

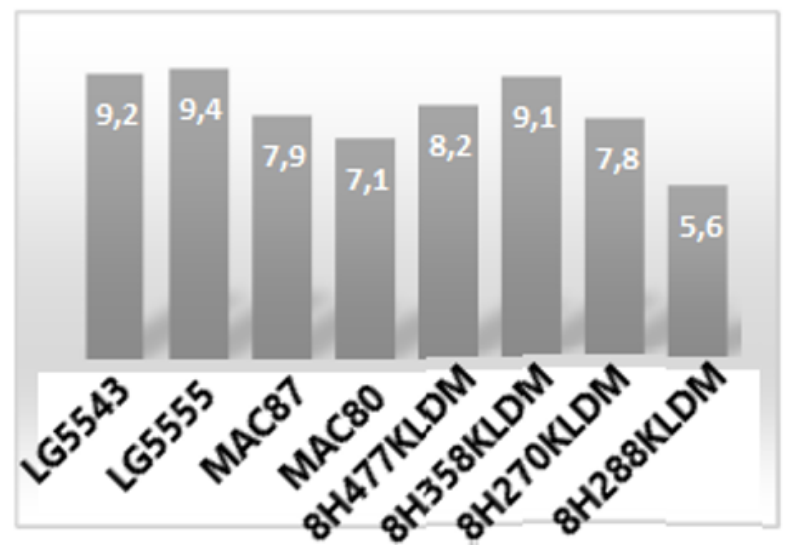

Fig. 3. An increase in the yield of sunflower seeds when using micronutrient mixtures and fertilizers for the options without treatments.

Thus, the analysis shows that the combined use of fertilizers and Agromineral significantly increased the yield of sunflower hybrids.

\section{Discussion}

The sunflower hybrids respond differently to fertilizers and micronutrient mixtures.

The use of fertilizers and Agromineral increases safety of plants to $87.9 \%$ (8H358KLDM) and $88.4 \%$ (8H270KLDM).

The maximum leaf area is formed in the budding phase ; in the flowering phase, it decreases.

The maximum value of the photosynthetic potential is achieved in $8 \mathrm{H} 477 \mathrm{KLDM}-4.386$ million $\mathrm{m}^{2} /$ ha days. In all hybrids, it is higher due to the use of fertilizers and Agromineral.

The combined use of micronutrient mixtures and fertilizers made it possible to obtain a fairly high yield up to $31.83 \mathrm{c} / \mathrm{ha}$.

\section{Conclusion}

In the conditions of the forest-steppe of the Middle Volga region, the use of fertilizers and Agromineral 3.0 1/ha ensures high safety of sunflower hybrids for harvesting $-81.5 \ldots 88.4 \%$.

The agricultural methods ensure the high photosynthetic potential (up to 4.386 million $\mathrm{m}^{2} / \mathrm{ha}$ ) and the net productivity of photosynthesis $(3.196 \ldots 6.079$ $\mathrm{g} / \mathrm{m}^{2)}$.

The crops yield can be up to $29.46 \ldots 31.83 \mathrm{c} / \mathrm{ha}$. The use of fertilizers (diammophos (N12P26K26), nitrabore (N15) and Agromineral increases the yield up to 9.36 c/ha.

\section{References}

1. A.D. Bochkova, Oilseeds Scientific and Technical Bulletin of the All-Russian Research Institute of Oilseeds 2(174), 120-134 (2018)

2. L.V. Karpova, Volga Niva 3(8), 22-27 (2008)

3. M.V. Kashukoev, Bulletin of RAAS 5, 30-32 (2014)

4. A.V. Makoveev, Political Mathematical Network Electronic Scientific J. of the Kuban State Agrarian University123, 1353-1367 (2016)

5. F. Mutlu, S. Bozcuk, Hacettepe J. Biol. \& Chem. 41(4), 331-339 (2013)

6. P Maury, M. Berger, F. Mojayad, C. Planchon, Plant and soil 1-2, 155-162 (2000)

7. D. A. Ward, J.A. Bunce, J. of experimental botany 12, 1842 (1986)

8. F. De Lillo, F. Cecconi, G. Lacorata, A. Vulpiani, EPL 84 (2008) 